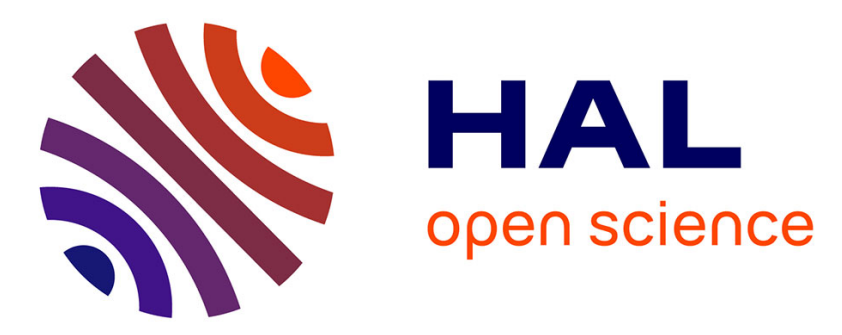

\title{
Predicting intentions to comply with speed limits using a 'decision tree' applied to an extended version of the theory of planned behaviour
}

Jimmy Bordarie

\section{- To cite this version:}

Jimmy Bordarie. Predicting intentions to comply with speed limits using a 'decision tree' applied to an extended version of the theory of planned behaviour. Transportation Research Part F: Traffic Psychology and Behaviour, 2019, 63, pp.174-185. 10.1016/j.trf.2019.04.005 . hal-02155284

\author{
HAL Id: hal-02155284 \\ https://hal.science/hal-02155284
}

Submitted on 22 Oct 2021

HAL is a multi-disciplinary open access archive for the deposit and dissemination of scientific research documents, whether they are published or not. The documents may come from teaching and research institutions in France or abroad, or from public or private research centers.
L'archive ouverte pluridisciplinaire HAL, est destinée au dépôt et à la diffusion de documents scientifiques de niveau recherche, publiés ou non, émanant des établissements d'enseignement et de recherche français ou étrangers, des laboratoires publics ou privés.

\section{(ㄷ)(1) $\$$}

Distributed under a Creative Commons Attribution - NonCommercial| 4.0 International 


\title{
Predicting intentions to comply with speed limits using a 'decision tree' applied
}

\section{to an extended version of the theory of planned behaviour}

\author{
Jimmy Bordarie \\ University of Tours - France \\ 29 Rue du Pont-Volant - 37082 Tours Cedex 2
}

Telephone: +33.778 .544 .803$

Email: jimmy.bordarie@univ-tours.fr 
1 Predicting intentions to comply with speed limits using a 'decision tree' applied to an extended version of the theory of planned behaviour

\section{Highlights}

- The extended version of the Theory of Planned Behaviour can be used to predict drivers' intentions to comply with a $30 \mathrm{~km} / \mathrm{h}$ speed limit.

- Perceived importance, perceived behaviour control and past behaviours are the most important factors.

- A decision tree helps optimize this prediction and makes it possible to compare reported intentions and theoretically expected intentions.

\section{Abstract}

Speed is a major cause of road traffic accidents and deaths. Public authorities address this issue by reducing speed limits, for example by extending the $30 \mathrm{~km} / \mathrm{h}$ speed limit throughout the urban area. This research is linked to the traffic-calming project in Angers (France). It is based on the Theory of Planned Behaviour (TPB) and the prediction of young drivers' intentions to comply with speed limits. We tested a modified version of the TPB that includes variables related to beliefs and other variables taken from the Self-Report Habit Index (SRHI). Participants $(\mathrm{n}=391$, Mean Age $=22.4, \mathrm{SD}=3.8)$ completed a questionnaire including measures of the TPB components related to intentions to comply with the $30 \mathrm{~km} / \mathrm{h}$ speed limit. Bayesian analysis confirmed the relevance of this model, which explained $53 \%$ of the variance of behavioural intention. By projecting these results on a decision tree, we were able to identify the most influential variables for predicting intentions. The interest of this decision tree is that it makes it possible to compare self-reported intentions and expected outcomes. The study provides support for politicians, researchers and communications officers who are responsible for implementing speed limit measures.

Keywords: Theory of Planned Behaviour; Self-Report Habit Index; decision trees; $30 \mathrm{~km} / \mathrm{h}$ speed limit

\section{Introduction}

Speed is a major factor in road traffic accidents and deaths (Aarts and van Schagen, 2006; Ayuso, Guillen and Alcaniz, 2010; De Winter and Dodou, 2010; Nilsson, 1982, 2004). This 
1 study focuses on drivers' intentions to comply with new legislation and public policies to reduce the speed limit. The research was carried out within the framework of the project of Angers (France) to extend the $30 \mathrm{~km} / \mathrm{h}$ speed limit throughout the city, except on boulevards and major roads where the limit remains $50 \mathrm{~km} / \mathrm{h}$. The aim of the study was to predict intentions to respect the speed limit using an extended version of the TPB to test several variables including beliefs and past behaviours. The latter were explored through the SRHI. In addition to drivers' self-reported intentions to respect the $30 \mathrm{~km} / \mathrm{h}$ speed limit, the current study used a decision tree to predict their intentions. The interest of the study lies in the comparison of drivers' self-reported intentions and their intentions as predicted by the decision tree.

\subsection{Calming traffic by extending the $30 \mathrm{~km} / \mathrm{h}$ speed limit}

In some French cities, the speed limit has been reduced from $50 \mathrm{~km} / \mathrm{h}$ (current legal speed limit in city centres) to $30 \mathrm{~km} / \mathrm{h}$ in order to promote well-being and improve safety. Indeed, the $30 \mathrm{~km} / \mathrm{h}$ speed limit considerably reduces the risk of fatality (Davis, 2001; Richards, 2010; Rosén and Sander, 2009; Rosén, Stigson and Sander, 2011) and the number of accidents in town (Bunn, Collier, Frost, Ker, Roberts and Wentz, 2003; Elvik, 2001; Grundy, Steinbach, Edwards, Green, Armstrong and Wilkinson, 2009). It is also associated with other effects related to the improvement of quality of life and well-being, such as reducing noise pollution (Spessert, Kühn, Leisker and Stiebritz, 2010) and enhancing social and commercial activities (Appleyard and Lintell, 1972; Certu, 2010; Rogers and Gumuchdjian, 2008). Research has demonstrated that heavy traffic leads to a decrease in the number of relationships and acquaintances (Appleyard and Lintell, 1972; Hart and Parkhurst, 2011) and social interactions with other people and neighbours (Sauter and Huettenmoser, 2008). Bordarie (2015) and Gaymard and Bordarie (2014) found that social representation of the ideal neighbourhood is associated with notions of "calm", "social interactions" and "access to shops and services". These aspects have been confirmed by other studies (Amérigo and Aragonés, 1988, 1990): calm and quietness of the area (Bender, Din, Faverger, Hoesli and Laakso, 1997), possibility of social links (Fine-Davis and Davis, 1982), and access to shops and services (Buys and Miller, 2012; Reynolds and Beamish, 2003; Sam, Bayram and Bilgel, 2012).

\subsection{Theory of Planned Behaviour and Self-Report Habit Index}

This research is based on the Theory of Planned Behaviour (TPB) (Ajzen, 1985, 1991, 2011; Ajzen and Albarracin, 2007; Ajzen and Madden, 1986). The aim is to examine the 
1 influence of social-cognitive factors on the intention to comply with speed limits. The results

2 of this study could have important implications for implementing speed limit reductions, and 3 also for developing road safety guidelines. The validity of the TPB has been largely demonstrated (Sheppard, Hartwick and Warshaw, 1988). According to the TPB, three factors can predict the intention to enact a behaviour: attitude, subjective norms and perceived behavioural control (PBC). This model also postulates that intention is the most relevant predictor of individuals' behaviours (Ajzen, 1985, 1991; Armitage and Conner, 2001; Madden, Scholder Ellen and Ajzen, 1992; Yzer, 2012). Attitude refers to the individual's positive or negative evaluation of a specific behaviour. Subjective norms are based on whether individuals think that people of importance to them (e.g. parents, friends) approve or disapprove of the behaviour. Finally, PBC refers to individuals' perceptions of their capacity to achieve the behaviour.

Multidimensional approaches within the TPB have shown that belief in the importance or impact of the behaviour can influence the individual's attitude or PBC (Ajzen, 1991). Moreover, past behaviours contribute to the prediction of behavioural intentions (Ajzen, 1991) and constitute the best predictor of future behaviour (Conner and Armitage, 1998; Ouellette and Wood, 1998). This finding was supported by Cestac (2009), who used the SelfReport Habit Index (SRHI) (Verplanken and Orbell, 2003) to predict the intention to buy a car. The SRHI measures several dimensions of habit: automatic activation, perceived ease, behavioural frequency, relevance to self-identity and history of enactment. It has been used in various fields, including dietary habits (Brug, de Vet, Wind, de Nooijer and Verplanken, 2006; Honkanen, Olsen and Verplanken, 2005) and mental habits (Verplanken, Friborg, Wang, Trafimow and Woolf, 2007).

\subsection{Application to traffic issues}

The SRHI has been used in the field of transportation and travel mode choices (Aarts, Verplanken and von Knippenberg, 1997; Verplanken, Myrbakk and Rudi, 2005), but it has never been used to understand drivers' habits with regard to speed or compliance with speed limits. On the other hand, research has shown the relevance of the TPB for mobility, risktaking and traffic issues; for example, the consumption of alcohol while driving (Marcil, 30 Bergeron and Audet, 2001; McGhie, Lewis and Hyde, 2012; Moan and Rise, 2011; Poulter, 31 Chapman, Bibby, Clarke and Crundall, 2008), the use of mobile phones while driving 32 (Nemme and White, 2010; Przepiorka, Błachnio and Sullman, 2018; Waddell and Wiener, 2014; White, Hyde, Walsh and Watson, 2010), the behaviour of pedestrians ( $\mathrm{Xu}, \mathrm{Li}$ and 
1 Zhang, 2013; Zhou, Horrey and Yu, 2009) and motorcyclists (Chen and Chen, 2011; Özkan,

2 Dogruyol, Lajunen, Yıldırım and Çoymak, 2012), and the importance of taking into account 3 cultural differences (Wallén Warner, Özkan and Lajunen, 2009). Concerning the compliance 4 with speed limits, numerous studies have used the TPB for motorists and motorcyclists (Chorlton, Conner and Jamson, 2012; Conner, Lawton, Parker, Chorlton, Manstead and Stradling, 2007; Elliott, 2010; Elliott, Armitage and Baughan, 2005; Elliott and Armitage, 2009; Elliott and Thomson, 2010; Eyssartier, 2010, 2012; Leandro, 2012; Wallén Warner and Åberg, 2006, 2008).

However, drivers often object to speed limit reduction measures (Australian Transport Safety Bureau, 2005). Compliance with speed limits usually depends on two major factors. First, speed is influenced by curved or straight sections, visibility and reliability of road signs and posted speed limits (Fitzpatrick, Carlson, Brewer and Wooldridge, 2001). Secondly, drivers generally drive faster than the limit that they themselves regard as being safe (Goldenbeld and van Schagen, 2007). Regarding the $30 \mathrm{~km} / \mathrm{h}$ speed limit in particular, Dinh and Kubota (2013a, 2013b, 2013c) found different profiles of drivers. Likewise, Toy, Tapp, Musselwhite and Davis (2014) and Bordarie (2015, 2016) identified several categories of drivers (in the United Kingdom and France respectively): 'champions' of the $30 \mathrm{~km} / \mathrm{h}$ speed limit, 'pragmatists' and 'opponents'.

\subsection{Decision trees}

In order to understand drivers' intentions to change some of their behaviours, we used decision trees (Quinlan, 1993), which have already been used in medicine and other research fields (Hastie, Tibshirani and Friedman, 2009). The interest of this tool is its ability to predict certain behaviours. First of all, decision trees are easy to interpret and understand, notably the difference between acceptable and unacceptable scenarios. They can thus be used to predict situations and/or determine outcome preferences in different contexts. In the latter case, alternative scenarios can be added. In this study, the decision tree compares drivers' selfreported intentions and their intentions predicted by their answers to questions related to the TPB and SRHI variables.

Ordinary trees consist of a root, branches, nodes and leaves. In statistics, decision trees are composed of circles (nodes) and segments (branches). The first node is the root. Two or several branches may grow from it. The last node of the chain is a leaf and no branches grow from it. Each node represents a variable, and branches give a set of values (called " $x$ " in 
1 Figure 1), which can be predicted from observations of individuals, social groups, or specific 2 characteristics.

3

4

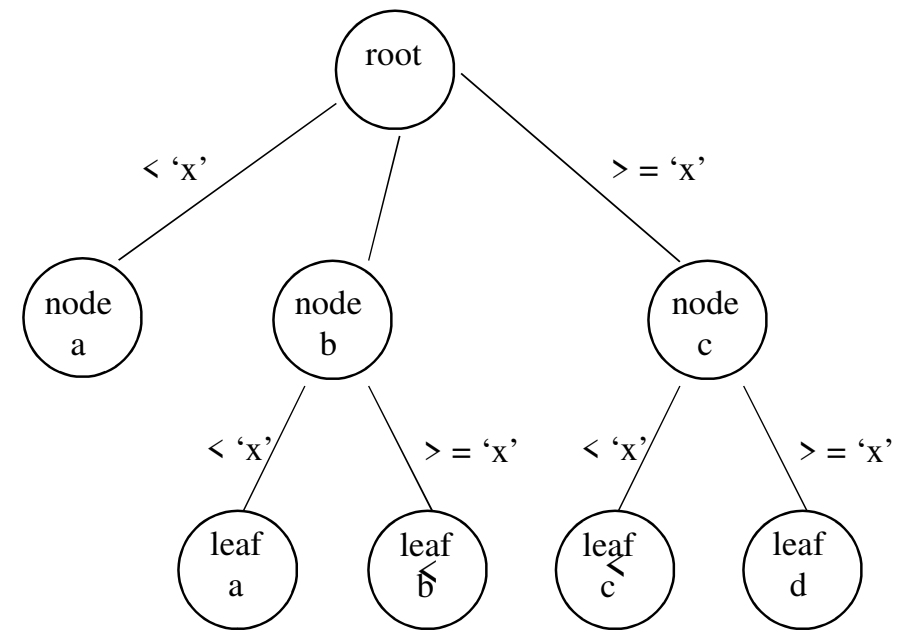

Figure 1. Example of a 'theoretical' decision tree

Decision trees have already been used in medicine (Li, Gluer, Eastell, Felsenberg, Reid, Rox and Lu, 2012; Nativ, Raz, Winkler, Hosaka, Boyle, Therneau, Farrow, Meyers, Zincke and Lieber, 1988; Podgorelec, Kokol, Stiglic and Rozman, 2002), and notably to identify significant predictors of child abuse in Canada (Fallon, Ma, Allan, Pillhofer, Trocmé and Jud, 2013). There are many ways of constructing a decision tree, but methods can be divided broadly into two groups: strictly optimum trees and approximately optimum trees. The main drawback of the former is that it involves a finite number of variables, while others could also influence the results. The latter has the disadvantage of being approximate and of relying on the population under study to construct the tree. According to Song and Lu (2015): "when the sample size is large enough, study data can be divided into training and validation datasets, using the training dataset to build a decision tree model and a validation dataset to decide on the appropriate tree size needed to achieve the optimal final model." This seems to be a good alternative to confirm the relevance of the decision tree.

\subsection{The current study}

Despite the considerable literature and the political measures taken to address issues of road safety, speed and traffic, drivers continue to take risks. The purpose of the current study is twofold. First, the main goal is to propose a model in which we expect (H1) that the TPB components could predict the intention to comply with the $30 \mathrm{~km} / \mathrm{h}$ speed limit, and $(\mathrm{H} 2)$ that 
1 past behaviours and habits identified from variables in the Self-Report Habit index would

2 have a significant effect on this intention. Secondly, the study aims to show the relevance of constructing decision trees directly from TPB data. This would make it possible to compare self-reported intentions and the theoretical intentions expected from the answers given to different variables. We assume (H3) that these would include the TPB variables. The discussion will seek to understand the results and explain various discrepancies. From an applied perspective, this research aims to provide information to understand the sociocognitive determinants of drivers' decisions and risk-taking behaviour and hence facilitate the implementation of speed limit reduction measures. It could also be of use when setting up road safety campaigns targeting drivers who do not comply with the speed limit.

\section{Method}

\subsection{Participants and procedure}

The sample $(\mathrm{n}=391)$ comprised $78 \%$ females $(\mathrm{n}=305)$ and $22 \%$ males $(\mathrm{n}=86)$ with a mean age of 21.79 years $(\mathrm{SD}=2.37)$ (range: 18-30). All participants were car drivers and students at the University of Angers. All the students at the University were sent an email inviting them to answer a questionnaire anonymously about the new public policy to extend the $30 \mathrm{~km} / \mathrm{h}$ speed limit throughout the city. Data were collected via an online questionnaire in French. In accordance with the ethics committee, participants were informed that their responses would be anonymous and confidential, and that their participation was voluntary and unpaid. In line with the recommendations of Song and Lu (2015) regarding construction of decision trees, the sample was split randomly into two groups with the same characteristics. The first group $(n=129)$ was used to construct the decision tree, and the second $(n=262)$ to validate the reliability of the tree.

\subsection{Instruments}

The questionnaire comprised fifteen items, based on the TPB and the SRHI. There were five items related to the TPB, based on the traditional dimensions of the model (attitude, subjective norms, PBC); the three items related to subjective norms concerned different social referents (parents, friends, motorists). Five further items, based on multidimensional approaches of the TPB, were related to cognitive aspects such as beliefs. Four items were related to behavioural aspects such as frequency, automaticity, history of enactment and ease; these items and the "identification" question were based on the SRHI.

The five items related to the traditional theory of planned behaviour were: 
- Attitude: I am in favour of driving within the $30 \mathrm{~km} / \mathrm{h}$ speed limit.

- Parental social norm: I think my parents are in favour of driving within the $30 \mathrm{~km} / \mathrm{h}$ speed limit.

- Social norm of friends: I think my friends are in favour of driving within the $30 \mathrm{~km} / \mathrm{h}$ speed limit.

- Social norm of motorists: I think motorists in general are in favour of driving within the $30 \mathrm{~km} / \mathrm{h}$ speed limit.

- PBC: I feel able to drive within the $30 \mathrm{~km} / \mathrm{h}$ speed limit.

The four items measuring beliefs relative to the behaviour were:

- Personal concern: driving within the $30 \mathrm{~km} / \mathrm{h}$ speed limit concerns me personally.

- Importance: driving within the $30 \mathrm{~km} / \mathrm{h}$ speed limit is important.

- Perceived effect: driving within the $30 \mathrm{~km} / \mathrm{h}$ speed limit has an effect.

- Perceived impact: driving within the $30 \mathrm{~km} / \mathrm{h}$ speed limit has an impact.

The five items measuring behavioural dimensions based on the SRHI were:

- Frequency: I often drive within the $30 \mathrm{~km} / \mathrm{h}$ speed limit.

- Automaticity: I automatically drive within the $30 \mathrm{~km} / \mathrm{h}$ speed limit, without thinking about it.

- Perceived ease: It's easy for me to drive within the $30 \mathrm{~km} / \mathrm{h}$ speed limit.

- History of enactment: I have driven within the $30 \mathrm{~km} / \mathrm{h}$ speed limit for a long time.

- Self-identity relevance (identification): driving within the $30 \mathrm{~km} / \mathrm{h}$ speed limit is typically 'me'.

Finally, one item measured intention:

- I will drive within the $30 \mathrm{~km} / \mathrm{h}$ speed limit wherever it is indicated.

Questions were presented randomly. Answers were given on a 6-point scale from 1 (completely disagree) to 6 (totally agree) in order to avoid neutral answers. We chose a scale of 1 to 6 rather than -3 to +3 in order to limit the impact of negative values on the answers (Schwarz, Knäuper, Hippler, Noelle-Neumann and Clark, 1991). Cronbach's alpha $(\alpha=.92)$ indicates very good reliability according to Nunnaly (1978).

\subsection{Data Analysis}

All analyses were conducted using SPSSStatistics version 21 and R software. This study aimed to show the interest of using Bayesian analysis to understand the levers predicting drivers' intentions to drive at $30 \mathrm{~km} / \mathrm{h}$. Although some psychological studies have used 
1 Bayesian analysis (van de Schoot, Winter, Ryan, Zondervan-Zwijnenburg and Depao, 2016),

2 this approach is still very rare in this field. Bayesian calculations are based on linear

3 regressions. Regarding our methodology with $\mathrm{R}$ software, we used the BayesFactor package

4 and the regressionBF function. The calculation method is based on the JZS (Rouder,

5 Speckman, Sun, Morey and Iverson, 2009). Here, intention is the dependent variable. By

6 using the 14 other questions as independent variables, we compared 16383 different models

7 with $\mathrm{R}$.

\section{Results}

3.1 Descriptive statistics and correlations

Correlations (Table 1) were calculated between TPB and SRHI determinants and behavioural intention with SPSS.

Table 1. Bravais-Pearson correlations

\begin{tabular}{|c|c|c|c|c|c|c|c|c|c|c|c|c|c|c|c|c|c|}
\hline & 1 & 2 & 3 & 4 & 5 & 6 & 7 & 8 & 9 & 10 & 11 & 12 & 13 & 14 & 15 & Mean & SD \\
\hline 1. Intention & 1.00 & $.62 * *$ & $.40 * *$ & $.37 * *$ & $.27 * *$ & $.55^{* *}$ & $.38 * *$ & $.28 * *$ & $.50 * *$ & $.44 * *$ & $.57 * *$ & $.48^{* *}$ & $.45^{* *}$ & $.49 * *$ & $.47 * *$ & 4.11 & 1.40 \\
\hline 2. Attitude & & 1.00 & $.64 * *$ & $.56 * *$ & $.46 * *$ & $.59 * *$ & $.45 * *$ & $.29 * *$ & $.73 * *$ & $.50 * *$ & $.51 * *$ & $.45^{* *}$ & $.49 * *$ & $.55^{* *}$ & $.52 * *$ & 3.54 & 1.49 \\
\hline 3. Parents norms & & & 1.00 & $.57 * *$ & $.50 * *$ & $.44 * *$ & $.39 * *$ & $.21 * *$ & $.54 * *$ & $.39 * *$ & $.38^{* *}$ & $.29 * *$ & $.35 * *$ & $.38 * *$ & $.35 * *$ & 3.47 & 1.42 \\
\hline 4. Friends norms & & & & 1.00 & $.55 * *$ & $.43 * *$ & $.28 * *$ & $.15^{* *}$ & $.51^{* *}$ & $.31^{* *}$ & $.38^{* *}$ & $.30^{* *}$ & $.27 * *$ & $.39 * *$ & $.37 * *$ & 2.89 & 1.12 \\
\hline 5. Motorists norms & & & & & 1.00 & $.28 * *$ & $.20 * *$ & $.12 *$ & $.36^{* *}$ & $.28^{* *}$ & $.26^{* *}$ & $.29 * *$ & $.25^{* *}$ & $.31 * *$ & $.30 * *$ & 2.45 & 1.07 \\
\hline 6. $\mathrm{PBC}$ & & & & & & 1.00 & $.34 * *$ & $.26^{* *}$ & $.46^{* *}$ & $.34^{* *}$ & $.45^{* *}$ & $.38^{* *}$ & $.50 * *$ & $.44^{* *}$ & $.40 * *$ & 4.24 & 1.45 \\
\hline 7. Concerning degree & & & & & & & 1.00 & $.26^{* *}$ & $.36^{* *}$ & $.30^{* *}$ & $.40^{* *}$ & $.26^{* *}$ & $.21 * *$ & $.37 * *$ & $.35^{* *}$ & 3.66 & 1.43 \\
\hline 8. Impact & & & & & & & & 1.00 & $.21^{* *}$ & $.17 * *$ & $.15^{* *}$ & $.11^{*}$ & .05 & $.15^{* *}$ & $.15^{* *}$ & 4.35 & 1.21 \\
\hline 9. Importance & & & & & & & & & 1.00 & $.44^{* *}$ & $.48^{* *}$ & $.41^{* *}$ & $.38 * *$ & $.54 * *$ & $.51 * *$ & 3.03 & 1.37 \\
\hline 10. Effect & & & & & & & & & & 1.00 & $.31 * *$ & $.22 * *$ & $.26^{* *}$ & $.29 * *$ & $.27 * *$ & 4.50 & 1.40 \\
\hline 11. Frequency & & & & & & & & & & & 1.00 & $.63^{* *}$ & $.41^{* *}$ & $.66^{* *}$ & $.68 * *$ & 3.01 & 1.35 \\
\hline 12. Automaticity & & & & & & & & & & & & 1.00 & $.45^{* *}$ & $.63^{* *}$ & $.62 * *$ & 2.56 & 1.29 \\
\hline 13. Perceived ease & & & & & & & & & & & & & 1.00 & $.47 * *$ & $.35^{* *}$ & 2.84 & 1.49 \\
\hline 14. Identification & & & & & & & & & & & & & & 1.00 & $.64 * *$ & 2.86 & 1.31 \\
\hline 15. Duration & & & & & & & & & & & & & & & 1.00 & 2.87 & 1.40 \\
\hline
\end{tabular}

Intention to comply with speed limits was strongly correlated with all the variables $(\mathrm{p}<.005)$. The SRHI variables were correlated with TPB variables, except for the perceived

20 importance of the $30 \mathrm{~km} / \mathrm{h}$ speed limit, which was not correlated with identification. These 21 findings support the view that habits are positively correlated with predictors of complying with speed limits.

\subsection{Predicting intention using a model combining TPB and SRHI}

Hierarchical regression analysis was conducted to analyse the impact of TPB, beliefs and SRHI variables on behavioural intentions (Table 2). In the current study, the variables relative 
1 to the TPB explained $43 \%$ of the variance $[F(5,385)=57.997, \mathrm{p}<.0001, \mathrm{r} 2=.43]$. This is a

2 good value. In a meta-analysis of 154 studies, Armitage and Conner (2001) found that TPB

3 generally explained $39 \%$ of the intention variance and $27 \%$ of the behaviour variance. In

4 comparison, by taking into account all the determinants of our model (Table 3), we explained

$553 \%$ of the variance for intention to comply with the $30 \mathrm{~km} / \mathrm{h}$ speed limit $[F(14,376)=30.25$,

$6 \mathrm{p}<.0001, \mathrm{r} 2=.53]$.

7 Table 2. Summary of models

\begin{tabular}{llcccccccc}
\hline \multicolumn{1}{c}{ Model } & R & \multicolumn{1}{c}{ R-2 } & R-2 adjusted & \multicolumn{1}{l}{ SE } & R-2 variation & F Variation & ddl1 & ddl2 & Sig. \\
\hline 1. TPB & $.655 \mathrm{a}$ & .430 & .422 & 1.067 & .430 & 57.997 & 5 & 385 & .000 \\
2. Beliefs & $.680 \mathrm{~b}$ & .463 & .450 & 1.041 & .033 & 5.862 & 4 & 381 & .000 \\
3. SRHI & $.728 \mathrm{c}$ & .530 & .512 & .981 & .067 & 10.718 & 5 & 376 & .000 \\
\hline
\end{tabular}

8

9 Table 3. Hierarchical regression analysis to predict intentions to comply with the

$10 \quad 30 \mathrm{~km} / \mathrm{hr}$ speed limit

\begin{tabular}{|c|c|c|c|c|c|c|}
\hline & \multirow[b]{3}{*}{ (Constante) } & \multicolumn{2}{|c|}{$\begin{array}{l}\text { Non-standardized } \\
\text { coefficients }\end{array}$} & \multirow{2}{*}{$\begin{array}{c}\begin{array}{l}\text { standardized } \\
\text { coefficients }\end{array} \\
\beta\end{array}$} & \multirow[t]{2}{*}{$\mathrm{t}$} & \multirow[t]{2}{*}{ Sig. } \\
\hline & & $\mathrm{A}$ & SD & & & \\
\hline & & 1.492 & .194 & & 7.708 & .000 \\
\hline \multirow{5}{*}{1} & Attitude & .438 & .055 & .465 & 8.012 & .000 \\
\hline & Parents norms & -.022 & .053 & -.022 & -.403 & .687 \\
\hline & Friends norms & .025 & .066 & .020 & .379 & .705 \\
\hline & Motorists norms & -.034 & .063 & -.026 & -.530 & .596 \\
\hline & PBC & .270 & .047 & .279 & 5.762 & .000 \\
\hline \multirow[t]{10}{*}{2} & (Constante) & 1.700 & .324 & & 5.251 & .000 \\
\hline & Attitude & .305 & .065 & .323 & 4.698 & .000 \\
\hline & Parents norms & -.062 & .053 & -.062 & -1.162 & .246 \\
\hline & Friends norms & .022 & .065 & .018 & .337 & .737 \\
\hline & Motorists norms & -.030 & .062 & -.023 & -.485 & .628 \\
\hline & PBC & .244 & .046 & .252 & 5.274 & .000 \\
\hline & Concerning degree & .089 & .043 & .091 & 2.092 & .037 \\
\hline & Impact & .078 & .046 & .067 & 1.681 & .093 \\
\hline & Importance & .070 & .058 & .069 & 1.210 & .227 \\
\hline & Effect & -.146 & .044 & -.146 & -3.300 & .001 \\
\hline \multirow[t]{15}{*}{3} & (Constante) & 2.035 & .406 & & 5.010 & .000 \\
\hline & Attitude & .229 & .063 & .243 & 3.638 & .000 \\
\hline & Parents norms & -.054 & .050 & -.055 & -1.084 & .279 \\
\hline & Friends norms & .012 & .062 & .010 & .195 & .846 \\
\hline & Motorists norms & -.049 & .059 & -.038 & -.838 & .403 \\
\hline & PBC & .157 & .046 & .162 & 3.392 & .001 \\
\hline & Concerning degree & .048 & .041 & .049 & 1.160 & .247 \\
\hline & Impact & .108 & .044 & .093 & 2.449 & .015 \\
\hline & Importance & .018 & .057 & .017 & .316 & .752 \\
\hline & Effect & -.143 & .042 & -.143 & -3.419 & .001 \\
\hline & Frequency & .242 & .058 & .232 & 4.138 & .000 \\
\hline & Automaticity & .121 & .056 & .111 & 2.146 & .033 \\
\hline & Perceived ease & -.089 & .043 & -.095 & -2.095 & .037 \\
\hline & Identification & -.034 & .059 & -.032 & -.570 & .569 \\
\hline & Duration & -.015 & .054 & -.015 & -.284 & .777 \\
\hline
\end{tabular}

$12 * * \mathrm{p} \leq .005$ 
The decision tree (Figure 2) is a model predicting participants' intentions to comply with the $30 \mathrm{~km} / \mathrm{h}$ speed limit. The first node (importance) refers to the question that is most decisive for predicting intention. By following the tree, we can find the other decisive questions. For example, to predict the intention to comply with the speed limit of a participant choosing a value higher than 2.5 for the variable related to the perceived importance of driving at $30 \mathrm{~km} / \mathrm{h}$, we need to follow the right side of the decision tree. Next, we must read the participant's answers to the questions regarding frequency, $\mathrm{PBC}$, attitude and eventually perceived parental norm. At the end of the tree, we obtain a number that corresponds to the theoretically expected intention of the participant. We can then compare this theoretical answer, corresponding to a prediction, with the participant's self-reported intention.

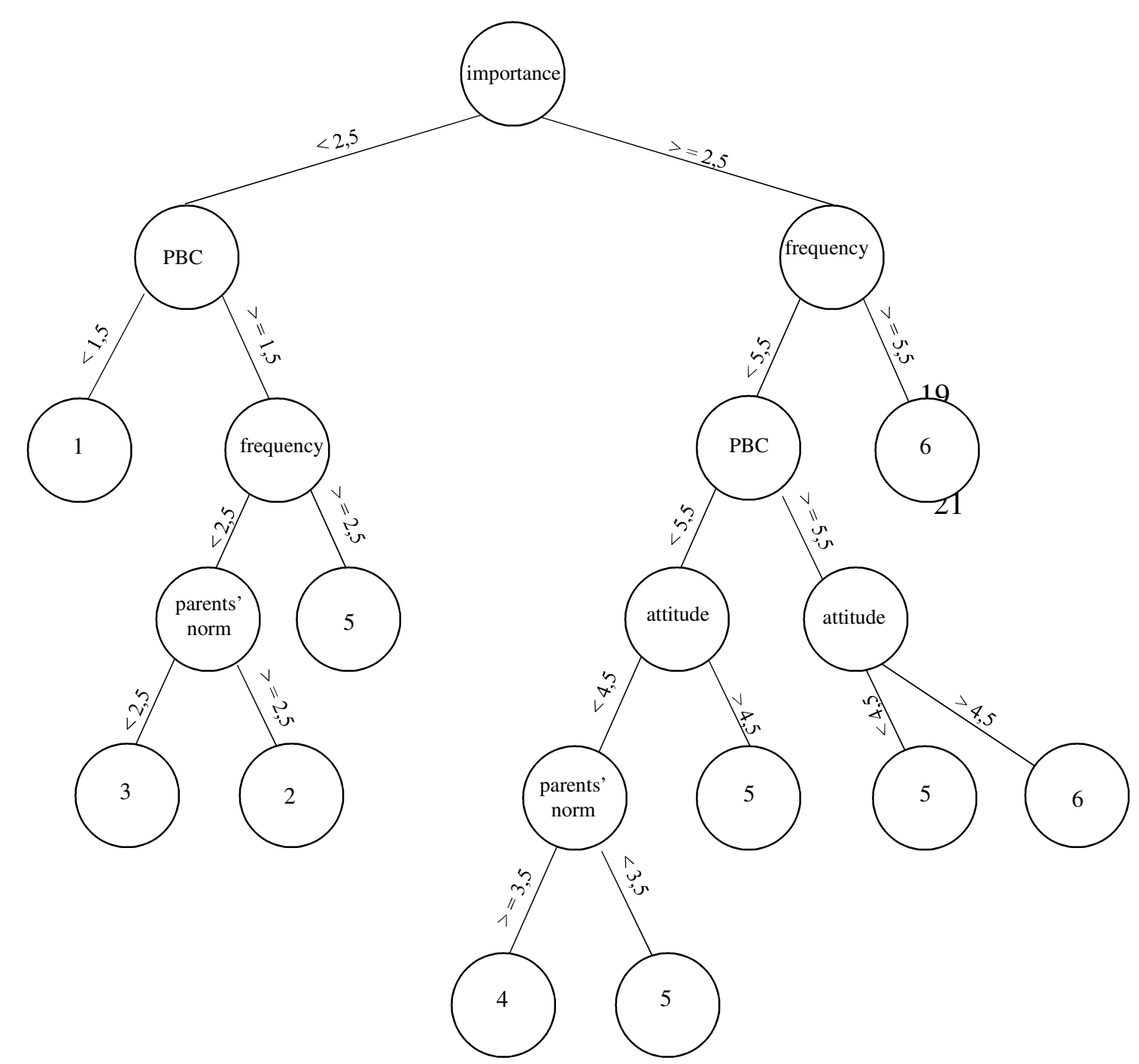

Figure 2. Decision tree contributing to predict the intention of driving at $30 \mathrm{~km} / \mathrm{h}$ 
To confirm the relevance of our model, we need to show its predictive value. Table 4 2 shows the comparison between reported intention and the prediction obtained with the 3 decision tree (data in bold in Table 4, i.e. the diagonal). These numbers reveal the 4 relationships between the two dimensions - reported and expected intention. The numbers in bold correspond to the number of participants for whom the predicted and self-reported intention values were the same (between 1 and 6). The number of participants for whom the value of the self-reported intention was the same as that of a different predicted intention (value of 1 to 6) is also shown. For instance, eight participants (number in italics) rated their intention with a value of 3 , but the decision tree prediction would have yielded a value of 5 .

Table 4. Data of the first group for constructing the decision tree

\section{Prediction}

\begin{tabular}{cccccccc}
\hline \multirow{5}{*}{ Intention } & & $\mathbf{1}$ & $\mathbf{2}$ & $\mathbf{3}$ & $\mathbf{4}$ & $\mathbf{5}$ & $\mathbf{6}$ \\
\cline { 2 - 7 } & $\mathbf{1}$ & $\mathbf{5}$ & 0 & 1 & 0 & 0 & 0 \\
& $\mathbf{2}$ & 1 & $\mathbf{7}$ & 3 & 2 & 3 & 0 \\
& $\mathbf{3}$ & 0 & 3 & $\mathbf{6}$ & 3 & 8 & 0 \\
& $\mathbf{4}$ & 0 & 2 & 0 & $\mathbf{1 9}$ & 12 & 2 \\
& $\mathbf{5}$ & 1 & 0 & 0 & 4 & $\mathbf{2 3}$ & 3 \\
& $\mathbf{6}$ & 0 & 0 & 0 & 1 & 5 & $\mathbf{1 5}$ \\
\hline
\end{tabular}

12

13

We can see that the decision tree suggests an exact prediction for 75 participants (i.e. $58.1 \%$ ). Random predictions would obtain an exact prediction for $16.67 \%$ of the participants. The difference between exact predictions and random predictions is significant $\left(\chi^{2}\right.$ Yates Correction $(\mathrm{YC})=14.47, \mathrm{df}=5, \mathrm{p}<.013)$. We can thus conclude that the decision tree influences exact predictions.

We can also analyse acceptable predictions, in other words, those equal to or within one point of difference with the participant's answer. In that situation, the decision tree makes an acceptable prediction for $84.5 \%$ participants (i.e. 109 participants). Random predictions taking into account this degree of freedom would be acceptable for $44.4 \%$ of the participants. The difference between acceptable predictions and random predictions is significant $\left(\chi^{2} \mathbf{Y C}=\right.$ 22.84, df $=5, \mathrm{p}<.001)$. We can therefore also conclude that the decision tree influences acceptable predictions. Thus, the decision tree in our model has a better predictive value than random predictions. 


\subsection{Validation of the decision tree}

We performed the same calculation with another group of participants $(n=262)$ in order to predict their intention with the help of the decision tree. We can see from Table 5 that the decision tree suggests an exact prediction for 97 participants (i.e. 37\%; $0.370=97 / 262$ ). Random predictions would give an exact prediction for $16.67 \%$ of participants. The difference between exact predictions and random predictions is significant $\left(\chi^{2} \mathbf{Y C}=41.86, \mathrm{df}=5, \mathrm{p}<\right.$ $.001)$. We can thus conclude that the decision tree always influences exact predictions.

We also examined acceptable predictions; the decision tree provided acceptable predictions for $79.4 \%$ of participants (i.e. 111 participants) $(0.794=(97+111) / 262)$. Random predictions taking into account this degree of freedom would be acceptable for $44.4 \%$ of participants. The difference between acceptable predictions and random predictions is significant $\left(\chi^{2} \mathrm{YC}=72.94, \mathrm{df}=5, \mathrm{p}<.001\right)$. We can thus conclude that the decision tree always influences acceptable predictions.

Table 5. Data of the second group in order to validate the decision tree

\begin{tabular}{cccccccc}
\multicolumn{7}{c}{ Prediction } \\
\hline \multirow{5}{*}{ Intention } & $\mathbf{1}$ & $\mathbf{2}$ & $\mathbf{3}$ & $\mathbf{4}$ & $\mathbf{5}$ & $\mathbf{6}$ \\
\cline { 2 - 8 } & $\mathbf{1}$ & $\mathbf{3}$ & 1 & 6 & 0 & 1 & 1 \\
& $\mathbf{2}$ & 4 & $\mathbf{4}$ & 8 & 2 & 6 & 0 \\
& $\mathbf{3}$ & 1 & 5 & $\mathbf{6}$ & 7 & 23 & 0 \\
& $\mathbf{4}$ & 1 & 3 & 7 & $\mathbf{2 3}$ & 39 & 2 \\
& $\mathbf{5}$ & 1 & 1 & 1 & 9 & $\mathbf{3 5}$ & 7 \\
\hline
\end{tabular}

The difference between predictions for the two groups is due to the data for the samples, as the decision tree was constructed from the data of the first group, composed of 129 participants. The tree is therefore related specifically to the data for that group, which explains the lower scores on the validation test. This is in fact one of the main criticisms of decision trees (Podgorelec, Kokol, Stiglic and Rozman, 2002). Nonetheless, the decision tree in our model has a better predictive value than random predictions.

\section{Discussion}

Speed is a major cause of road traffic deaths and injuries. To address this problem, many European cities, such as Angers in France, introduce speed limit reductions. The purpose of the current study was to investigate the determinants of drivers' intentions to comply with the 
1 new speed limit of $30 \mathrm{~km} / \mathrm{h}$. We wished to test TPB factors (attitude, subjective norms, PBC)

2 (Ajzen, 1991, 2011) (H1) and variables linked to drivers' habits using variables from the Self-

3 Report Habit Index (Verplanken and Orbell, 2003) (H2). Finally, we constructed a decision

4 tree in order to compare self-reported intentions and the intentions predicted by the participants' responses to TPB and SRHI factors (H3).

\subsection{Predictive factors of the intention to comply with the $30 \mathrm{~km} / \mathrm{h}$ speed limit}

The results confirmed the relevance of the TPB for predicting the intention to comply with the $30 \mathrm{~km} / \mathrm{h}$ speed limit. However, subjective norms of parents, friends or motorists in general were not significant. Thus, we cannot confirm our first hypothesis. This result is in line with findings that social norms constitute a minor predictor (Krueger, Reilly and Carsrud, 2000), whereas other studies have found that they are the strongest predictor of driving violations (Parker, Manstead, Stradling and Reason, 1992a, 1992b; Wallén Warner and Åberg, 2006, 2008). The additional dimensions of the extended version of the TPB show that beliefs influence attitudes, subjective norms and PBC (Ajzen, 1991). However, regarding the subjective norms, our results can be explained in two ways: either we did not measure a reference group that is large enough for respondents regarding the specific behaviour of driving at $30 \mathrm{~km} / \mathrm{h}$. It would probably have been wise to add an item such as "Most people who are important to me think that I should drive within the $30 \mathrm{~km} / \mathrm{h}$ limit". Though, the results of a previous study show that drivers with less than 3 years of driving licence like in our sample seem to be more influenced by their parents' models than by their friends or motorists in general with regard to $30 \mathrm{~km} / \mathrm{h}$ (Bordarie, 2014). Or maybe our results are explained by the fact that we measured attitudinal beliefs attributed to others about driving at $30 \mathrm{~km} / \mathrm{h}$ rather than their beliefs or expectations about what the respondent should do according to each reference group. Perhaps we could have formulated the item as follows: "My parents expect me to drive within the $30 \mathrm{~km} / \mathrm{h}$ limit".

Legitimacy concerned the belief that lowering the speed limit could reduce the number of accidents (Kanellaidis, Golias and Zarifopoulos, 1995). Research has also shown that past behaviour plays a role in determining intentions (Bamberg, Ajzen and Schmidt, 2003; de Bruijn, Kremers, Singh, van den Putte and van Machelen, 2009; Conner and Armitage, 1998;

30 Forward, 2009; Potard, Kubiszewski, Camus, Courtois and Gaymard, 2018). Moreover, our 31 results indicate the role of several variables related to habits in general (Bordarie 2015; Cestac, 2009); three out of five dimensions of the SRHI (frequency, perceived ease and automaticity) were found to predict intention. This confirms our second hypothesis. However, 
1 identification with the issue and duration of the behaviour were not significant. We observed

2 a link between the three predictive aspects of the SRHI and the PBC, which could thus be 3 directly influenced by these aspects.

\subsection{Relevance of using a decision tree}

In this study, we used Bayesian analysis to analyse the data. The creation of a decision tree to predict intention confirms our third hypothesis (H3). This method is relevant for at least two reasons. First, the study of the intention is easier, faster and more effective because the tree takes into account the most predictive variables. Secondly, the decision tree makes it possible to compare drivers' reported intentions to respect the $30 \mathrm{~km} / \mathrm{h}$ speed limit and their theoretical intentions expected from their answers about the other variables. When the two values (self-reported intention and theoretical intention) are equal, the predictive value of our model and the relevance of the tree are confirmed. When they differ, it would be interesting to examine in more depth the reasons for the discrepancy. Individuals' explanations provide important data to understand acceptance of speed limits and the intention to comply with them. Recent studies have shown the role of the rationalization process when a person is faced with contradictory aspects of cognition and behaviour (Bordarie, 2015, 2017). It would be interesting to focus on participants whose answers reveal a discrepancy between self-reported and expected intentions.

The tree underlines the role of TPB factors (attitude, subjective norms, and PBC) in predicting the intention to comply with the $30 \mathrm{~km} / \mathrm{h}$ speed limit. However, linear regression analysis suggests that subjective norms were not significant. The tree also confirms the role of beliefs, such as the perceived importance of the speed limit. This validates the idea that drivers are more likely to respect speed limits when they consider that they are legitimate (Goldenbeld and van Schagen 2007) and can reduce accidents (Kanellaidis, Golias and Zarifopoulos 1995). Finally, the tree includes one of the SRHI factors (frequency) that can be linked to PBC. Indeed, we can assume that when a behaviour is frequently enacted, it is then easier to feel able to carry it out in the future. As a result, the $\mathrm{PBC}$ is stronger.

\subsection{Limitations}

Some limitations can be mentioned. First of all, the study is based on self-reported data. Regarding compliance with the law, in this case, respecting the $30 \mathrm{~km} / \mathrm{h}$ speed limit, this raises questions about validity and social desirability. However, we attempted to minimize this problem by guaranteeing anonymity and confidentiality. Secondly, the sample is not representative of the general population, as it was composed uniquely of students with a 
1 majority of females. This could be relevant, because males generally take more risks and are

2 more involved in driving offences (Cordellieri, Baralla, Ferlazzo, Sgalla, Piccardi \& Giannini, 3 2016). Thirdly, studying behavioural intentions is useful, because it is one the most predictive

4 factors of behaviour; however, it is important to note that intentions and behaviours are different. Bordarie and Gaymard (2015a, 2015b) studied self-reported and actual behaviours with regard to the $30 \mathrm{~km} / \mathrm{h}$ speed limit, and they found that drivers' practices were strongly influenced by specific situations. It would be interesting to extend this study by following up behaviour in-situ.

\section{Conclusion and practical implications}

This research has a number of implications. First, it confirms the efficacy of an extended version of the TPB in predicting drivers' intentions to comply with a speed limit that may appear problematic, such as a reduction from $50 \mathrm{~km} / \mathrm{h}$ to $30 \mathrm{~km} / \mathrm{h}$. Secondly, using a decision tree is an interesting way to understand certain discrepancies between self-report questionnaires and behaviour that can be predicted from TPB variables. This study can thus be seen as a bridge between behavioural intentions and social thinking, helping understand why people sometimes say they will do something but fail to do so.

From an applied perspective, the current study could be of interest to local authorities wishing to extend the $30 \mathrm{~km} / \mathrm{h}$ speed limit. First, before starting such a project, the tool we created could be used to gain information about citizens' and drivers' intentions with regard to this measure. Policy makers can imagine specific applications of this tool to determine the kind of streets in which the $30 \mathrm{~km} / \mathrm{hr}$ speed limit could be more relevant than in others according to drivers' intentions. Indeed, as we have seen in the theoretical framework, studies have already shown that some street configurations are more conducive to the implementation of such a speed limit. Policy makers and road engineers could thus, in a transparent approach, question the population and rely on their expertise as users to determine to what extent the system would really be interesting and respected.

Secondly, data obtained by this type of tool can be used in communication campaigns. Indeed, communication can be enhanced by taking into account individuals' attitudes, ideas and actual practices, and communications officers could use the decision tree to create effective campaigns. For instance, the decision tree showed us that when drivers feel they can't drive at $30 \mathrm{~km} / \mathrm{h}$ speed limit, then their attitude towards $30 \mathrm{~km} / \mathrm{h}$ is negative and their 
aspects related to the "perceived capacity" to drive at $30 \mathrm{~km} / \mathrm{hr}$ speed limit in order to increase this feeling among drivers to optimize their intention to comply with this speed limit, in particular by improving their attitude towards it.

\section{Acknowledgements}

There is no conflict of interest.

This work was supported by Angers City Hall (France) [grant: 1689/2011].

The author specially acknowledges Alexandre Laurent from the University of Angers for his support, his help and advice during this research.

\section{References}

Aarts, L., and Schagen, I van. (2006). Driving speed and the risk of road crashes: A review. Accident Analysis and Prevention, 38(2), 215-224. https://doi.org/10.1016/j.aap.2005.07.004

Aarts, H., Verplanken, B., \& Knippenberg, A. van (1997). Habit and information use in travel mode choices. Acta Psychologica, 96, 1-14. https://doi.org/10.1016/S00016918(97)00008-5

Ajzen, I. (1985). From intentions to actions: A theory of planned behavior. In J. Kuhl and J. Beckman (Eds.), Action control from cognition to behavior (pp. 11-39). Heidelberg, Germany: Springer.

Ajzen, I. (1991). The theory of planned behavior. Organizational Behavior and Human Decision Processes, 50, 179-211. https://doi.org/10.1016/0749-5978(91)90020-T

Ajzen, I. (2011). The theory of planned behaviour: Reactions and reflections. Psychology and Health, 26, 1113-1127. https://doi.org/10.1080/08870446.2011.613995

Ajzen, I., and Albarracin, D. (2007). Predicting and changing behavior: A reasoned action approach. In I. Ajzen, D. Albarracin, and R. Hornik (Eds.), Prediction and Change of Health Behavior: Applying the reasoned action approach (pp. 3-21). Mahwah, NJ: Lawrence Erlbaum Associates Publishers.

Ajzen, I., and Madden, T. J. (1986). Prediction of goal-directed behavior: Attitudes, intentions, and perceived behavioral control. Journal of Experimental Social Psychology (Print), 22(5), 453-474. https://doi.org/10.1016/0022-1031(86)90045-4 
Amérigo, M., and Aragonés, J. I. (1988). Satisfacción residencial en un barrio remodelado: Predictores fisicos y sociales. Revista de Psicología Social, 3(1), 61-70. https://doi.org/10.1080/02134748.1988.10821574

Amérigo, M., and Aragonés, J. I. (1990). Residential satisfaction in council housing. Journal of Environmental Psychology, 10(4), 313-325. https://doi.org/10.1016/S02724944(05)80031-3

Appleyard, D., and Lintell, M. (1972). The environmental quality of city streets: the residents' viewpoint. Journal of the American Institute of Planners, 38(2), 84-101. Retrieved from http://www.edra.org/sites/default/files/publications/EDRA03-Appleyard-11-2_0.pdf

Armitage, C. J., and Conner, M. (2001). Efficacy of the theory of planned behaviour: A metaanalytic review. British journal of social psychology,40(4), 471-499. https://doi.org/10.1348/014466601164939

Australian Transport Safety Bureau (2005). Community attitudes towards road safety: Community attitudes survey wave 18. Report N CR 227.

Ayuso, M, Guillén, M., and Alcañiz, M. (2010). The impact of traffic violations on the estimated cost of traffic accidents with victims. Accident Analysis and Prevention, 42(2), 709-717. https://doi.org/10.1016/j.aap.2009.10.020

Bamberg, S., Ajzen, I., and Schmidt, P. (2003). Choice of travel mode in the theory of planned behavior: The roles of past behavior, habit and reasoned action. Basic and Applied Social Psychology, 25, 175-187. https://doi.org/10.1207/S15324834BASP2503_01.

Bender, A., Din, A., Favarger, P., Hoesli, M., and Laakso, J. (1997). An Analysis of Perceptions Concerning the Environmental Quality of Housing in Geneva. Urban Studies 34(3), 503513. https://doi.org/10.1080/0042098976104

Bordarie, J. (2015). Représentations sociales et mobilité urbaine durable. Thèse de Doctorat, Université d'Angers.

Bordarie, J. (2016). A highlight of the relationship between thêmata and social representations using a hierarchical clustering method. Review of Psychology, 23(1-2), 27-38. https://doi.org/10.21465/rp0023.0003

Bordarie, J. (2017). Rationalization processes between social representations and semantic blocks theory. In D. Compagno (Dir.), Quantitative Semiotic Analysis. Springer. 
1 Bordarie, J., and Gaymard, S. (2015a). Représentations sociales et comportements à l'égard $\mathrm{du} 30 \mathrm{~km} / \mathrm{h}$ : pratiques rapportées et pratiques effectives. In S. Gaymard and T. Tiplica (Dirs.), Sécurité, éducation et mobilités : Maîtrise des risques et prévention Tome 2 (pp. 151-164). Paris: L'harmattan.

Bordarie, J., and Gaymard, S. (2015b). Social representations and public policy: influence of the distance from the object on representational valence. Open Journal of Social Sciences (ISSN: 2327-5952), 3, 300-305. https://doi.org/10.4236/jss.2015.39038

Breitman, L., Friedman, J.H., Olshen, R.A., and Stone, C.J. (1984). Classification and Regression Trees. Wadsworth, Belmont, California.

Brug, J., de Vet, E., de Nooijer, J., and Verplanken, B. (2006). Predicting fruit consumption: cognitions, intention and habits. Journal of Nutrition Education and Behaviour, 38(2), 73-81. https://doi.org/10.1016/j.jneb.2005.11.027

Bunn, F., Collier, T., Frost, C., Ker, K., Roberts, I., and Wentz, R. (2003). Area-wide traffic calming for preventing traffic related injuries. Cochrane Database of Systematic Reviews, 1. https://doi.org/10.1002/14651858

Buys, L., and Miller, E. (2012). Residential satisfaction in inner urban higher-density Brisbane, Australia: role of dwelling design, neighborhood and neighbors. Journal of Environmental Planning and Management, 55(3), 319-338. https://doi.org/10.1080/09640568.2011.597592

CERTU. (2010). Zones de circulation apaisée, fiche n4 (août 2010). Disponible www.certu.fr

Cestac, J. (2009). Habitude et principe de compatibilité dans le modèle du comportement planifié: décisions pro-environnementales et automobile. Thèse de Doctorat, Université de Nanterre-Paris X.

Chen, C.-F., and Chen, C.W. (2011). Speeding for fun? Exploring the speeding behavior of riders of heavy motorcycles using the theory of planned behavior and psychological flow theory. Accident Analysis and Prevention, 43(3), 983-990. https://doi.org/10.1016/j.aap.2010.11.025

Chorlton, K., Conner, M., and Jamson, S. (2012). Identifying the psychological determinants of risky riding: An application of an extended Theory of Planned Behaviour. Accident Analysis and Prevention, 49, 142-153. https://doi.org/10.1016/j.aap.2011.07.003 
1 Conner, M., and Armitage, C. J. (1998). Extending the theory of planned behavior: A review and avenues for further research. Journal of Applied Social Psychology, 28, 1429-1464. https://doi.org/10.1111/j.1559-1816.1998.tb01685

Cordellieri, P., Baralla, F., Ferlazzo, F., Sgalla, R., Piccardi, L., and Giannini, A. M. (2016). Gender Effects in Young Road Users on Road Safety Attitudes, Behaviors and Risk Perception. Frontiers in psychology, 7 , 1412. https://dx.doi.org/10.3389\%2Ffpsyg.2016.01412

Davis, G. A. (2001). Relating severity of pedestrian injury to impact speed in vehicle-vehiclepedestrian crashes. Transportation Research Record, 1773, 108-113. https://doi.org/10.3141/1773-13

de Bruijn, G.-J., Kremers, S. P. J., Singh, A., van den Putte, B., and van Machelen, W. (2009). Adult active transportation: Adding habit strength to the theory of planned behavior. American Journal of Preventive Medicine, 36, 189-194. https://doi.org/10.1016/j.amepre.2008.10.019

de Winter, J. C. F., and Dodou, D. (2010). The Driver Behaviour Questionnaire as a predictor of accidents: A meta-analysis. Journal of Safety Research, 41, 463-470. https://doi.org/10.1016/j.jsr.2010.10.007

Dinh, D. D., and Kubota, H. (2013a). Profile-speed data-based models to estimate operating speeds for urban residential streets with a 30km/h speed limit. IATSS Research, 36(2), 115-122. https://doi.org/10.1016/j.iatssr.2012.06.001

Dinh, D. D., and Kubota, H. (2013b). Speeding behavior on urban residential streets with a $30 \mathrm{~km} / \mathrm{h}$ speed limit under the framework of the theory of planned behavior. Transport Policy, 29, 199-208. https://doi.org/10.1016/j.tranpol.2013.06.003

Duy Dinh, D., and Kubota, H. (2013c). Drivers' perceptions regarding speeding and driving on urban residential streets with a $30 \mathrm{~km} / \mathrm{h}$ speed limit. IATSS Research, 37(1), pp. 30-38. https://doi.org/10.1016/j.iatssr.2012.12.001

Elliott, M.A. (2010). Predicting motorcyclists' intention to speed: Effects of selected cognitions from the theory of planned behaviour, self-identity and social identity. Accident Analysis and Prevention, 42, 718-725. https://doi.org/10.1016/j.aap.2009.10.021 
1 Elliott, M.A., and Thomson, J.A. (2010). The social cognitive determinants of offending drivers' speeding behaviour. Accident Analysis and Prevention, 42, 1595-1605. https://doi.org/10.1016/j.aap.2010.03.018

Elliott, M. A., Armitage, C. J., and Baughan, C. J. (2005). Exploring the beliefs underpinning drivers' intentions to comply with speed limits. Transportation Research Part F: Traffic Psychology and Behaviour, 8, 459-479. https://doi.org/10.1016/j.trf.2005.08.002

Elvik, R. (2001). Area-wide urban traffic calming schemes: a meta-analysis of safety effects. Accident Analysis and Prevention, 33(3), 327-336. https://doi.org/10.1016/S0001$\underline{4575(00) 00046-4}$

Eyssartier, C. (2010). Transgression de la limitation de vitesse par les motards : facteurs incitateurs et inhibiteurs/ Motorcyclists transgression of speed limits. Actes du colloque international ITFH Infrastructures, Technologies et Facteurs Humaines : approche multidisciplinaire de la sécurité dans les moyens de transport. Angers : Université d'Angers, 2010, p.25-26.

Eyssartier, C. (2012). Dépassement de la limitation de vitesse sur route limitée à $90 \mathrm{~km} / \mathrm{h}$ : étude sur les motards peu expérimentés du département de la Sarthe. In S. Gaymard and A. Egido (Eds.), Sécurité et facteurs humains dans les transports : une approche multidisciplinaire (pp. 253-266). Paris: L'Harmattan.

Fallon, B., Ma, J., Allan, K., Pillhofer, M., Trocmé, N., and Jud, A. (2013). Opportunities for prevention and intervention with young children: lessons from the Canadian incidence study of reported child abuse and neglect. Child and adolescent psychiatry and mental health, 7(1), 4. https://doi.org/10.1186/1753-2000-7-4

Fine-Davis, M., and Davis, E.E. (1982). Predictors of Satisfaction with Environmental Quality in Eight European Countries. Social Indicators Research, 11(4), 341-362. https://doi.org/10.1007/BF00323186

Fitzpatrick, K., Carlson, P., Brewer, M., and Wooldridge, M. (2001). Design factors that affect driver speed on suburban streets. Transportation Research Record: Journal of Transportation Research Board, 1751, 18-25. https://doi.org/10.3141/1751-03

Forward, S. E. (2009). The theory of planned behavior: The role of descriptive norms and past behavior in the prediction of drivers' intention to violate. Transportation Research Part F: Traffic Psychology and Behaviour, 12, 198-207. https://doi.org/10.1016/j.trf.2008.12.002 
Gaymard, S., and Bordarie, J. (2014). The perception of the ideal neighborhood in a changing city : a preamble to implementation of a street use code. Social indicators research, 120(3), 801-816. https://doi.org/10.1007/s11205-014-0610-1

Goldenbeld, C., and Schagen, I. van (2007). The credibility of speed limits on $80 \mathrm{~km} / \mathrm{h}$ rural roads: the effects of road and person(ality) characteristics. Accident Analyses and Prevention, 39 (6), 1121-1130. https://doi.org/10.1016/j.aap.2007.02.012

Grundy, C., Steinbach R., Edwards, P., Green, J., Armstrong, B., and Wilkinson, P. (2009). Effect of $20 \mathrm{mph}$ traffic speed zones on road injuries in London, 1986-2006: controlled interrupted time series analysis. BMJ, 339, 1-6. https://doi.org/10.1136/bmj.b4469

Hart, J., and Parkhurst, G. (2011). Driven to excess: Impacts of motor vehicles on the quality of life of residents of three streets in Bristol UK. World Transport Policy and Practice, 17(2), 12-30. Retrieved from http://citeseerx.ist.psu.edu/viewdoc/download?doi=10.1.1.577.4439 $\&$ rep=rep $1 \&$ type $=$ pdf

Hastie, T., Tibshirani, R., and Friedman, J. (2009). The elements of statistical learning. New York. NY: Springer.

Honkanen, P., Olsen, S.O., and Verplanken, B. (2005). Intention to consume seafood-the importance of habit. Appetite, 45(2), 161-168. https://doi.org/10.1016/j.appet.2005.04.005

Kanellaidis, G., Golias, J., and Zarifopoulos, K. (1995). A survey of drivers' attitudes toward speed. Journal of Safety Research, 26(1), 31-40. http://psycnet.apa.org/doi/10.1016/0022-4375(94)00025-5

Krueger Jr, N.F., Reilly, M.D., and Carsrud, A.L. (2000). Competing models of entrepreneurial intentions. Journal of business venturing, 15(5-6), 411-432. https://doi.org/10.1016/S0883-9026(98)00033-0

Leandro, M. (2012). Young drivers and speed selection: A model guided by the Theory of Planned Behavior. Transportation Research Part F: Traffic Psychology and Behaviour, 15(3), 219-232. https://doi.org/10.1016/j.trf.2011.12.011

Li, C., Gluer, C.C., Eastell, R., Felsenberg, D., Reid, D.M., Rox, D.M., and Lu, Y. (2012). Treestructured subgroup analysis of receiver operating characteristic curves for diagnostic tests. Academic Radiology, 19(12), 1529-1536. https://doi.org/10.1016/j.acra.2012.09.007 
1 Madden, T.J., Scholder Ellen, P.S., and Ajzen, I. (1992). A comparison of the theory of planned behavior and the theory of reasoned action. Personality and Social Psychology Bulletin, 18, 3-9. https://doi.org/10.1177/0146167292181001

Marcil, I., Bergeron, J., and Audet, T. (2001). Motivational factors underlying the intention to drink and drive in young male drivers. Journal of Safety Research, 32, 361-376. https://doi.org/10.1016/S0022-4375(01)00062-7

McGhie, A., Lewis, I., and Hyde, M.K. (2012). The influence of conformity and group identity on drink walking intentions: comparing intentions to drink walk across risky pedestrian crossing scenarios. Accident Analysis and Prevention, 45(2), 639-645. https://doi.org/10.1016/j.aap.2011.09.035

Moan, I., and Rise, J. (2011). Predicting intentions not to "drink and drive" using an extended version of the theory of planned behavior. Accident Analysis and Prevention, 43(4), 1378-1384. https://doi.org/10.1016/j.aap.2011.02.012

Nativ, O., Raz, Y., Winkler, H. Z., Hosaka, Y., Boyle, E. T., Therneau, T. M., and Lieber, M. M. (1988). Prognostic value of flow cytometric nuclear DNA analysis in stage C prostate carcinoma. In Surgical Forum, 39, 685-687. American College of Surgeons.

Nemme, H., and White, K. (2010). Texting while driving: psychosocial influences on young people's texting intentions and behaviour. Accident Analysis and Prevention, 42(4), 1257-1265. https://doi.org/10.1016/j.aap.2010.01.019

Nilsson, G. (1982). The effects of speed limits on traffic accidents in Sweden. In: Proceedings of the international symposium on the effects of speed limits on traffic accidents and transport energy use, 6-8 October 1981, Dublin. OECD, Paris, p. 1-8.

Nilsson, G. (2004). Traffic safety dimensions and the power model to describe the effect of speed on safety. Lund Bulletin 221. Lund Institute of Technology, Lund. Retrieved from https://www.motor-talk.de/forum/aktion/Attachment.html?attachmentId=689000

Nunnaly, J. (1978). Psychometric theory. New York: McGraw-Hill.

Ouellette, J. A., and Wood, W. (1998). Habit and intention in everyday life: The multiple processes by which past behavior predicts future behavior. Psychological Bulletin, 124, 54-74. https://doi.org/10.1037/0033-2909.124.1.54 
1 Ozkan, T., Doğruyol, L., Lajunen, T., Yıldırım, Z., and Çoymak, A. (2012). Motorcycle 49, 124-32. https://doi.org/10.1016/j.aap.2011.03.009

Parker, D., Manstead, A. S. R., Stradling, S. G., and Reason, J. T. (1992a). Determinants of intention to commit driving violations. Accident Analysis and Prevention, 24, 117-131. https://doi.org/10.1016/0001-4575(92)90028-H

Parker, D., Manstead, A. S. R., Stradling, S. G., and Reason, J. T. (1992b). Intention to commit driving violations: An application of the theory of planned behavior. Journal of Applied Psychology, 77, 94-101. https://doi.org/10.1037/0021-9010.77.1.94

Podgorelec, V., Kokol, P., Stiglic, B., and Rozman, I. (2002). Decision trees: an overview and their use in medicine. Journal of medical systems, 26(5), 445-463. https://doi.org/10.1023/A:1016409317640

Potard, C., Kubiszewski, V., Camus, G., Courtois, R., and Gaymard, S. (2018) Driving under the influence of alcohol and perceived invulnerability among young adults: An extension of the theory of planned behavior. Transportation Research Part F, 55, 38-46. https://doi.org/10.1016/j.trf.2018.02.033

Poulter, D.R., Chapman, P.R., Bibby, P.A., Clarke, D., and Crundall, D.E. (2008). An application of the Theory of Planned Behaviour to truck driving behaviour and compliance with regulations. Accident Analysis and Prevention, 40, 2058-2064. https://doi.org/10.1016/j.aap.2008.09.002

Przepiorka, A. M., Błachnio, A. P., and Sullman, M. J. (2018). Factors influencing intentions to text while driving among Polish drivers. Transportation Research Part F: Traffic Psychology and Behaviour, 55, 306-313. https://doi.org/10.1016/j.trf.2018.03.015

Quinlan, J.R. (1993). C4.5: Programs for Machine Learning, Morgan Kaufmann, San Francisco.

Reynolds, S.G., and Beamish, J.O. (2003). Residential satisfaction of older adults in age segregated facilities. Housing and Society, 30(1), 33-49. https://doi.org/10.1080/08882746.2003.11430481

Richards, D.C. (2010). Relationship between speed and risk of fatal injury: pedestrians and car occupants. Road Safety Web publication, 16. DfT, London. Retrieved from 
https://nacto.org/docs/usdg/relationship_between_speed_risk_fatal_injury_pedestrians_a nd_car_occupants_richards.pdf

Rogers, R.G., and Gumuchdjian, P. (2008). Des Villes durables pour une petite planète. Paris: Moniteur.

Rosen, E., and Sander, U. (2009). Pedestrian fatality risk as a function of car impact speed. Accident Analysis and Prevention, 41(3), 536-542. https://doi.org/10.1016/j.aap.2009.02.002

Rosen, E., Stigson, H., and Sander, U. (2011). Literature review of pedestrian fatality risk as a function of car impact speed. Accident Analysis and Prevention, 43(1), 25-33. https://doi.org/10.1016/j.aap.2010.04.003

Rouder, J.N., Speckman, P.L., Sun, D., Morey, R.D., and Iverson, G. (2009). Bayesian t-tests for accepting and rejecting the null hypothesis. Psychonomic Bulletin and Review, 16, 225-237. https://doi.org/10.3758/PBR.16.2.225

Sam, N., Bayram, N., and Bilgel, N. (2012). The perception of residential environment quality and neighbourhood attachment in a metropolitan city: A study on Bursa, Turkey. eCanadian Journal of Humanities and Social Sciences, 1(1), 22-39. Retrieved from https://www.researchgate.net/profile/Nazan_Bilgel/publication

Sauter, D., and Huettenmoser, M. (2008). Liveable streets and social inclusion. Urban Design International, 13(2), 67-79. https://doi.org/10.1057/udi.2008.15

Schwarz, N., Knäuper, B., Hippler, H.J., Noelle-Neumann, E., and Clark, F. (1991). Rating scales: Numeric values may change the meaning of scale labels. Public Opinion Quarterly, 55, 570-582. https://doi.org/10.1086/269282

Sheppard, B., Hartwick, J., and Warshaw, P. (1988). The theory of reasoned action: A metaanalysis of past research with recommendations for modifications and future research. Journal of Consumer Research, 15(3), 325. https://doi.org/10.1086/209170

Song, Y. and Lu, Y. (2015). Decision tree methods: applications for classification and prediction. Shanghai Archives of Psychiatry, 27(2), 130-135. https://doi.org/10.11919/j.issn.1002-0829.215044

Spessert, B., Kühn, B., Leisker, C., and Stiebritz, M. (2010). Vergleichende messtechnische Untersuchungen zum Einfluss einer nächtlichen Geschwindigkeitsbegrenzung von $50 \mathrm{~km} / \mathrm{h}$ 
auf $30 \mathrm{~km} / \mathrm{h}$ auf die Lärmimmissionen durch den Straßenverkehr. University of Applied Sciences Jena. Retrieved from www.jena.de/fm/41/Bericht_Tempo_30_W03_101111.pdf

Toy, S., Tapp, A., Musselwhite, C., and Davis, A. (2014). Can social marketing make 20mph the new norm? Journal of Transport and Health, 1(3), 165-173. http://dx.doi.org/10.1016/j.jth.2014.05.003

Van de Schoot, R., Schalken, N., and Olff, M. (2017). Systematic search of Bayesian statistics in the field of psychotraumatology. European Journal of Psychotraumatology, 8(1). https://doi.org/10.1080/20008198.2017.1375339

Verplanken, B., and Orbell, S. (2003). Reflections on Past Behavior: A Self-Report Index of Habit Strength1. Journal of Applied Social Psychology, 33(6), 1313-1330. https://doi.org/10.1111/j.1559-1816.2003.tb01951.x

Verplanken, B., Friborg, O., Wang, C.E., Trafimow, D., and Woolf, K. (2007). Mental habits: Metacognitive reflection on negative self-thinking. Journal of Personality and Social Psychology, 92(3), 526. https://doi.org/10.1037/0022-3514.92.3.526

Verplanken, B., Myrbakk, V., and Rudi, E. (2005). The measurement of habit. In T. Betsch and S. Haberstroh (Eds.), The routines of decision making (pp. 231-247). In S. Gaymard and A. Egido (Eds.), Sécurité et facteurs humains dans les transports : une approche multidisciplinaire (pp. 253-266). Mahwah, NJ: Lawrence Erlbaum.

Waddell, L. P., and Wiener, K. K. K. (2014). What's driving illegal mobile phone use? Psychosocial influences on drivers' intentions to use handheld mobile phones. Transportation Research Part F: Traffic Psychology and Behaviour, 22, 1-11. https://doi.org/10.1016/j.trf.2013.10.008

Wallén Warner, H., and Åberg, L. (2006). Drivers' decision to speed: A study inspired by the theory of planned behavior. Transportation Research Part F: Traffic Psychology and Behaviour, 9, 427-433. https://doi.org/10.1016/j.trf.2006.03.004

Wallén Warner, H., and Åberg, L. (2008). Drivers' beliefs about exceeding the speed limits. Transportation Research Part F: Traffic Psychology and Behaviour, 11, 376-389. https://doi.org/10.1016/j.trf.2008.03.002

Wallén Warner, H., Özkan, T., and Lajunen, T. (2009). Cross-cultural differences in drivers' speed choice. Accident Analysis and Prevention, 41(4), 816-819. https://doi.org/10.1016/j.aap.2009.04.004 
1 White, K. M., Hyde, M. K., Walsh, S. P., \& Watson, B. (2010). Mobile phone use while 2 driving: An investigation of the beliefs influencing drivers' hands-free and hand-held mobile phone use. Transportation Research Part F: Traffic Psychology and Behaviour, 13(1), 9-20. https://doi.org/10.1016/j.trf.2009.09.004

Xu, Y.S., Li, Y.J., and Zhang, F. (2013). Pedestrians' intention to jaywalk: Automatic or 6 planned? A study based on a dual-process model in China. Accident Analysis and Prevention, 50, 811-819. https://doi.org/10.1016/j.aap.2012.07.007

Yzer, M. (2012). Perceived behavioral control in reasoned action theory: A dual-aspect interpretation. The Annals of the American Academy of Political and Social Science, 640, 101-117. https://doi.org/10.1177/0002716211423500

11 Zhou, R., Horrey, W.J., and Yu, R. (2009). The effect of conformity tendency on pedestrians' 12 road-crossing intentions in China: An application of the Theory of Planned Behavior. 